\title{
Solaropsis brasiliana, anatomy, range extension and its phylogenetic position within Pleurodontidae (Mollusca, Gastropoda, Stylommatophora)
}

\author{
MARÍA GABRIELA CUEZZO ${ }^{1}$, AUGUSTO P. DE LIMA ${ }^{2}$ and SONIA B. DOS SANTOS ${ }^{2}$ \\ ${ }^{1}$ Instituto de Biodiversidad Neotropical/CONICET-UNT, Crisóstomo Álvarez, 722, 4000 Tucumán, Argentina \\ ${ }^{2}$ Instituto de Biologia Roberto Alcantara Gomes, Universidade do Estado do Rio de Janeiro, Rua \\ São Francisco Xavier, 524, PHLC, Sala 525-2, 20550-900 Rio de Janeiro, RJ, Brazil
}

Manuscript received on April 7, 2017; accepted for publication on October 13, 2017

\begin{abstract}
A detailed anatomical revision on Solaropsis brasiliana (Deshayes 1832) has been carried out. New characters on shell, anatomy of soft parts, and a review of the genus distribution in South America, as well as clarification on $S$. brasiliana distributional area are provided in the present study. Solaropsis brasiliana is diagnosed by its globose, solid, and hirsute shell, with periphery obsoletely angular, bursa copulatrix with a thick, long diverticulum, a thick, long flagellum and a penis retractor muscle forked, with the vas deferens passing through it. This compiled information was used to test the phylogenetic position of S. brasiliana within South American Pleurodontidae through a cladistics analysis. In the phylogenetic hypothesis obtained, S. brasiliana is sister group of S. gibboni (Pfeiffer 1846) and the monophyly of the genus Solaropsis Beck is also supported. Here, we sustain that the distribution of S. brasiliana is restricted to Brazil, inhabiting the States of Rio de Janeiro, Espírito Santo, Bahia and Minas Gerais.
\end{abstract}

Key words: Brazil, distribution, morphology, phylogeny, taxonomy.

\section{INTRODUCTION}

The genus Solaropsis Beck 1837, as well as the other American taxa formerly classified into Camaenidae, has a complex systematic history that has yet to be untangled. Pleurodontidae was proposed by Ihering (1912) to replace the name Camaenidae when he analyzed the South American Helices, since this family contains Pleurodonte Fischer von Waldheim 1807 that pre dates Camaena Albers 1850. Wurtz (1955) rejected this idea considering that Camaena was the type genus

Correspondence to: Maria Gabriela Cuezzo

E-mail: gcuezzo@webmail.unt.edu.ar of Camaenidae, therefore, according to the rules of International Code of Zoological Nomenclature, the name of the family was correct. Wurtz retained the American taxa in Camaenidae but excluded the current Ammonitellidae, Oreohelicidae, Polygyratia Gray 1847 and Solaropsis. He also proposed a subdivision of the resting American taxa into four major genera complexes.

Richardson (1985) listed a total of 44 nominal names in Solaropsis and re-classified it into Camaenidae. Solaropsis species of Brazil were reviewed by Ihering (1900).

Later in 1986, Nordsieck created the family Solaropsidae that included two genera, Solaropsis 
and Psadara Miller, 1878 that, together with Camaenidae, formed Camaenoidea. According to Nordsieck (1986), the jaw and kidney in Solaropsidae were like those in Camaenidae, but the genital system had what he assumed to be plesiomorphic characters (presence of a diverticulum in the bursa copulatrix, a penial appendix and forked penial retractor). Other authors maintained Solaropsis together with the other American taxa into Camaenidae (Zilch 1959-1960, Cuezzo 2002, 2003). Morphological evidence used for a cladistics analysis supported the monophyly of Camaenidae (Cuezzo 2003) and showed an arrangement of the American genera in two clades, a first one formed by Pleurodonte and a second formed by Eurycratera Beck 1837, Polydontes Montfort 1810, Zachrysia Pilsbry 1894, Caracolus Montfort 1810, Isomeria Albers 1850, Solaropsis and Labyrinthus Beck 1837. Within this last clade, all the South American taxa formed a monophyletic unit with Caracolus as sister group.

Posterior phylogenetic analyses based on molecular evidence, using a scarce representation of American genera and a total absence of South American species, sustained that Camenidae was polyphyletic (Wade et al. 2006). Bouchet and Rocroi (2005) classified the American genera of the former Camaenidae, into Pleurodontidae. Subsequent studies on Helicoidea, based on molecular evidence (Wade et al. 2007), continued supporting the American taxa into Pleurodontidae, which was divided into two different groups, Polydontes and Zachrysia in a clade, and a second clade with Pleurodonte and Thelidomus Swainson 1840. Unfortunately, as in previous molecular hypotheses, there were no representatives in these last studies (Wade et al. 2006, 2007) of the South American genera Isomeria, Labyrinthus, and Solaropsis.

The systematic position of Solaropsis is problematic due to its scarce general knowledge, and lack of anatomical and molecular information on most of its species. The data available comes mostly from studies on shell characters based on scarce number of specimens. The tendency by early conchologists to describe taxa on the basis of just one or two shells had contributed to the poor diagnosis of the genus.

Solaropsis brasiliana (Deshayes 1832) is a species emblematic to Rio de Janeiro State, often found in Ilha Grande (Haas 1953, Santos et al. 2010, Nunes and Santos 2012). The taxonomic identification of material preserved in collections is often confused with Solaropsis pilsbryi Ihering 1900 and also with $S$. gibboni because of the lack of a clear diagnosis. Recent collections carried out by researchers of Universidade do Estado do Rio de Janeiro (UERJ), provided soft new material and new information on habitat preferences allowing a redescription of this species.

Here we describe and figure the shell and anatomy, especially focused on the genitalia and radula of Solaropsis brasiliana, review the known distribution of the genus Solaropsis in South America, giving precise localization of S. brasiliana, and discuss about its phylogenetic position in relation to other American Pleurodontidae.

\section{MATERIALS AND METHODS}

Hand collection of live adult specimens and dry shells of Solaropsis brasiliana were carried out on the Atlantic Forest ecoregion (Paraná biogeographical Dominion), mainly from Ilha Grande, Rio de Janeiro State in Brazil. Malacology collections from Museums and Universities were also reviewed or different electronic data bases consulted to collect distributional data: American Museum Natural History, NY, USA (AMNH), Florida History Museum (FLMNH), Field Museum Natural History, Chicago, USA (FMNH), Global Biodiversity Information Facility (GBIF), Instituto de Biodiversidad Neotropical, Tucuman, Argentina (IBN); Instituto-Fundación Miguel Lillo, Tucumán, 
Argentina (IFML), Museo de La Plata, Buenos Aires, Argentina (MLP), Museo de Zoologia de la Pontifica Universidad Catolica del Ecuador, Quito, Ecuador (QCAZ), National Museum of Natural History of Paris, France (MNHN), Museu Nacional do Rio de Janeiro, RJ, Brazil (MNRJ), Museu de Zoologia da Universidade de São Paulo, Brazil (MZSP), Natural History Museum of London, England (NHMUK), Universidade do Estado do Rio de Janeiro, RJ, Brazil (UERJ). Only precise localities of occurrences were taken into account to build the distribution areas of the Solaropsis species. Additional localities were compiled from Haas (1953), Solem (1966), Tillier (1980) and Cuezzo (2002, 2006).

Live specimens were drawn in water for relaxation previous to fixation in alcohol $96 \%$, body preservation was done using alcohol $75 \%$. Shells were photographed with a camera Nikon 5300 and posteriorly measured using the software ImageJ 1.49. Dissections were carried out under a Nikon SMZ800 microscope and illustrations were made with the aid of a camera lucida. Photographs of the different organ systems were obtained with a Zeiss Stemi 508 with ActionCam and final art was made with the software Corel Draw x3. Terminology used for descriptions of the reproductive system follows Tompa (1984), pallial and digestive follows Tillier (1989). Terms proximal and distal refers to the position of an organ or part of an organ in relation to the gamete flow from ovotestis (proximal) to genital pore (distal) as in previous works (Cuezzo 2003, 2006). Distinction limits between epiphallus and penis is based on the internal sculpture of their inner wall. Radula, jaw and shell were observed and photographed with a SEM Zeiss Supra 55VP at the Integral Center of Electron Microscopy of the National University of Tucumán, Argentina. Supragenera classification follows Bouchet and Rocroi (2005).

Distribution was analyzed and illustrated with Quantum Gis Geographic information System
(QGIS 2.8) Open Source Geospatial Foundation Project. http://qgis.osgeo.org.

\section{PHYLOGENETIC ANALYSIS}

\section{Taxon sampling}

The ingroup consisted on 21 species of the genera Solaropsis, Isomeria and Labyrinthus, for which material, other than only dry shells were available. The cladistic analysis here performed is based in a matrix previously used for the analysis of the former Camaenidae (Cuezzo 2003), restricting it only to the characters and taxa of Pleurodontidae species. Information here provided for $S$. brasiliana was coded and included in the matrix. The species Isomeria aequatoriana (Pfeiffer 1860), I. awa Cuezzo 2006, I. cymatodes (Pfeiffer 1853), I. oreas (Koch in Philippi 1845), Olympus nimbus Simone 2010 and Labyrinthus ellipsostomus (Pfeiffer 1854) were also added to the matrix for a better genera representation. Trees were rooted in Caracolus caracolus (Linne 1758) and Caracolus marginella (Gmelin 1791), sister groups of the continental Pleurodontidae, according to the previous phylogenetic hypothesis (Cuezzo 2003). In the case of Olympus nimbus, characters were coded based on Simone (2010).

\section{CLADISTIC METHODS}

Characters analyzed were modified from those provided in Cuezzo (2003). Six new continuous characters on shell measurements have been added to 40 discrete morphological characters on soft parts (Tables SI, SII - Supplementary Material). Discrete characters have been codified according to Sereno (2007). Everytime a character number is mentioned in the text, it is followed by the state character in brackets.

The data matrix of 46 characters and 23 taxa was built using WINCLADA v.1.00.08 (Nixon 2002) (Table SII). Missing entries are indicated by "?". Multistate characters were treated as additive. 
Cladistic analyses were performed with TNT version 1.5 (Goloboff et al. 2003, 2008), a free software for parsimony analysis that allows the incorporation of continuous characters. Character Weighting, and Traditional Search basing the strategy on RAS + TBR (random addition sequences plus swap by tree bisection and reconnection), with 1,000 replications and 100 trees saved per replication was used. Concavity (K) value was stablished as default $(\mathrm{K}=3000)$. The implied weighting method takes into account the congruence between characters during tree searches. As the phylogeny is judged to be the most important source of correlation between characters, those characters that are more congruent to each other, are also supposed to be the most correlated with the phylogeny, and therefore more weight is attributable to them during searches (Mirande et al. 2013). Clade support was estimated using symmetric resampling, because the resulting values obtained under this procedure are not distorted by character weighting (Goloboff et al. 2003). Additionally, jackknife resampling method, as a measure of degree of support, or as a measure of whether the hypothesis of monophyly for the group in question involves character conflict, was also calculated.

\section{RESULTS}

\section{TAXONOMY}

\section{Family Pleurodontidae}

\section{Genus Solaropsis Beck 1837}

Helix (Solaropsis) Beck 1837: 27

Diagnostic characters of the genus Solaropsis: Shell with round-like aperture, body whorl not descending behind the aperture, shell surface with rounded to oval granules, except in Solaropsis feisthameli (Hupe 1853) and S. gibboni. Lung roof extending beyond top of the kidney. Diverticulum departing from bursa copulatrix duct. Penial appendix present in some species. Forked penial muscular retractor.

\section{TYPE SPECIES}

Helix pellis serpentis Chemnitz 1795 (= Helix undata Lightfoot 1786), by subsequent designation (Herrmannsen 1848 [1847-1849]: 468).

\section{DISTRIBUTION}

The genus Solaropsis is distributed from Costa Rica to the south reaching northern Argentina, and from Colombia to the east reaching Suriname and French Guiana. Brazil, Ecuador and Peru hold most of its species. Unfortunately, most of the dry material preserved in Museums and malacology collections, have imprecise locality records, citing only the country where they were collected. These records allow knowing species presence in a country, but do not provide information on the specific area they inhabit, as well as its habitat preferences. Countries like Venezuela, Guyana and Suriname have very low number of records, although it is known that some species of Solaropsis do occur. In other cases, species determination is lacking, especially referring to material from Bolivia, deposited in different Museums. From the total of the records gathered, the majority are coincident with tropical and subtropical rainforest areas. Occurrence records are mainly distributed in a north-western part (north-western South America and Amazonian forest) and a south-eastern part (Paraná and Atlantic forest) (Figure 1). Only Solaropsis bachi Ihering 1900 (Minas Gerais) and S. gibboni (Goiás) have registered records in dry open areas of the Cerrado ecoregion (Chacoan biogeographical dominion), while $S$. heliaca (d'Orbigny 1835) (Argentina) occurs in the Dry Chaco area ecoregion (also part of the Chacoan biogeographical dominion).

\section{Solaropsis brasiliana (Deshayes, 1832)}

Helix brasiliana Deshayes 1832: 211; Beck 1837: 27; Deshayes in Ferussac and Deshayes 1851: 65; Reeve 1851: fig. 536; Pfeiffer 1848: 372; Hupé 


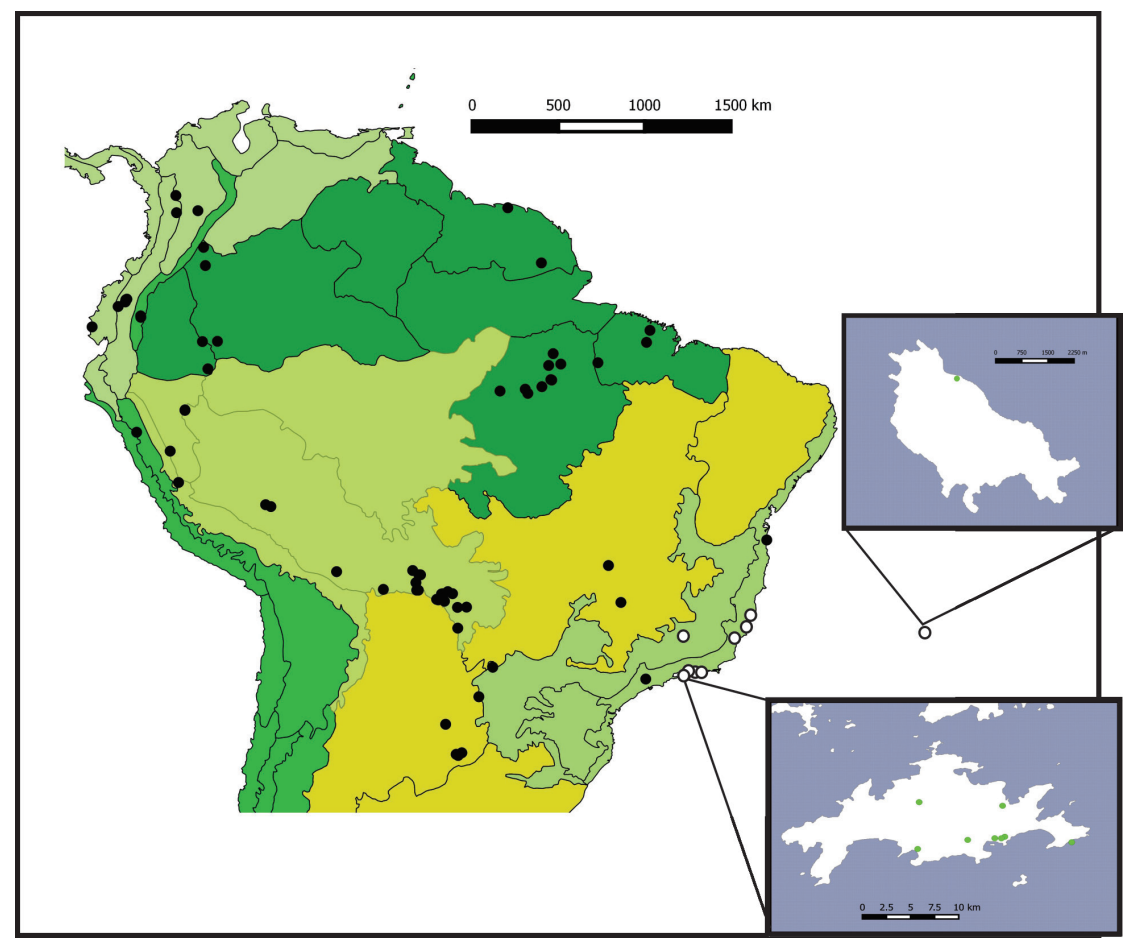

Figure 1 - Area of distribution of the genus Solaropsis. Biogeographical regionalization of Morrone (2014) at the Dominion level. Shapefile implementation according to Lowënberg-Neto (2014). Biogeographic dominions: Yungas; Boreal Brazilian; Chacoan; Pacific; Paraná; South Brazilian. $\bullet=$ Solaropsis species records; $\bigcirc=$ Solaropsis brasiliana .

1857: 8, P1.II fig. 2; Pfeiffer 1868: 373; Hidalgo 1869: 9.

Helix (Solaropsis) brasiliana: Albers 1850: 127; Albers 1860: 164; Kobelt 1879: 252.

Helix (Solaropsis) braziliana Pilsbry 1889: 184. [incorrect subsequent spelling]

Solaropsis brasiliana Ihering, 1900: 547; Tillier 1980: 127; Cuezzo 2003; Campos Salgado and Coelho 2003: 172; Simone 2006: 240.

Solaropsis braziliana: Morretes 1949: 163; Haas 1953: 205. [incorrect subsequent spelling]

TYPE MATERIAL MNHN-IM-2000-1846- Bresilsyntypes.

TYPE LOCALITY “Bresil” (Brazil).

\section{ADDITIONAL MATERIAL EXAMINED}

BRAZIL. (FMNH 252, FMNH 40779, AMNH 58656, 190182). Rio de Janeiro: Casimiro de Abreu (Distrito de Aldeia Velha, Fazenda Bom Retiro),
20/03/1994, S. Barboza "Peninha" leg., UERJ 382. Duque de Caxias, 1941, MNRJ 5735. Mangaratiba (Reserva Ecológica Rio das Pedras), 28/04/1994, A.C. Souza leg., UERJ 432; (Cachoeirinha do Cedro), 2/1959, Rubias, A. Cohelo \& L. Castro leg, MNRJ 2753. Muriqui, 15/01/1956, MNRJ 1935. Angra dos Reis (Ilha Grande), H. Sick leg., FMNH 43816; (Ilha Grande), J.F. Zikán leg., FMNH 47106; (Ilha Grande, Trilha do Caxadaço), 15/08/1996, S.B. Santos leg., UERJ 639, 640; (Ilha Grande, Trilha da Jararaca), 29/08/2002, S.B. Santos leg., UERJ 1735, 634, 1212; (Ilha Grande, Vila Dois Rios, Trilha do Bambual), 24/01/2000, S.B. Santos leg. UERJ 1549; (Vila Dois Rios, Trilha da Jararaca, Rio Andorinhas), 27/04/2003, F. Hatano leg. UERJ 2977; (Ilha Grande, Vila Abraão), 2008, Lopez \& Silva leg., UERJ 7299; (Ilha Grande, Vila dos Rios, Trilha da Jararaca), A.F. Barbosa leg. 1998, MNRJ 8132. Saquarema 
(Palmital), 25/4/1999, MNRJ 7927; Rio de Janeiro (Jacarepaguá, Estrada Represa de Camorim), 22/02/1991, L. Alvarenga leg., MNRJ 6170; (Tijuca, Caminho Pedro do Conde), 9/1944, MNRJ 213; (Alto da Boa Vista), H.S. Lopes leg., MNRJ 3376. Minas Gerais, 1972, Toffalini col., MNRJ 42352. Espírito Santo, Serra (Monte Mestre), Helio do SiSa leg., MNRJ 31664; Santa Cruz, 6/1972, C.S. Ferrlin \& Brown col., MNRJ 18850; Ilha da Trindade (Praia dos Cabritos), A. Coelho, S. Ypiranga \& J. Becker leg., MNRJ 3428; Linhares (Fazenda Cupido), 2/3/1948, MNRJ 753.

\section{SYSTEMATIC DESCRIPTIONS}

\section{External morphology}

Animal body coloration dark to blackish, lighter in the caudal zone. Cephalic region long, with dorsal line lined by dark pigmented lateral zone. Long foot with pointed extreme. Sole not divided. Ommatophores dark with pale cream tips (Figure 2).

\section{SHELL}

Shell globose, four to five $1 / 2$ whorls, thin but solid, densely hirsute (Figures 2, 3a). Last whorl convex with upper body whorl periphery obsoletely angular. Spire moderately depressed, obtuse. Shell surface with regularly arranged rounded to oval granules. (Figure 3b) granule bearing short hairs, which are lost in dry and worn shells of probable old animals. Protoconch smooth (Figure 3c). Shell chestnut to dark brown in color, more pale in ventral side. Dorsal shell portion with two narrow spiral bands, one subsutural and other suprasutural. Subsutural spiral band formed by well-defined D-shaped chestnut marks, over pale cream ground. Suprasutural spiral band formed by thinner chestnut D shaped marks, over a pale chestnut ground (Figure 3a). Subsutural spiral bands more noticeable to naked eyes. Body whorl with a double band of D-shaped chestnut spots on cream ground,

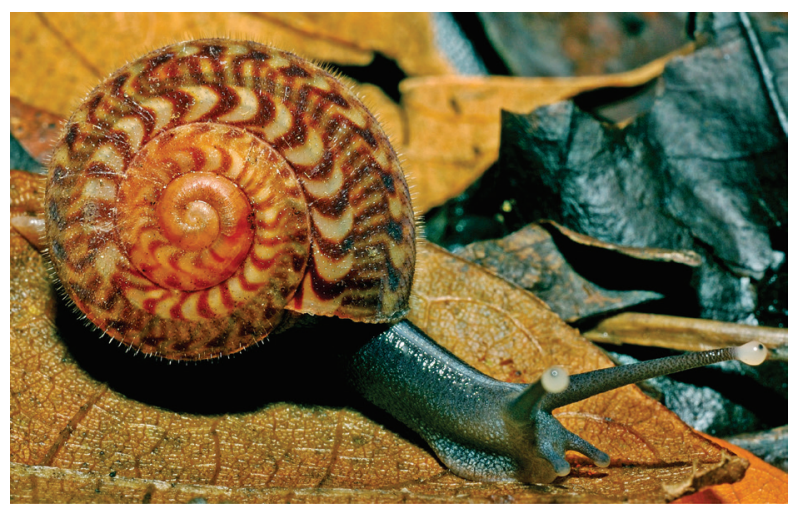

Figure 2 - Live Solaropsis brasiliana showing soft body coloration and hirsute shell. Photograph courtesy of Prof. Dr. Antonio Carlos de Freitas (IBRAG-UERJ).
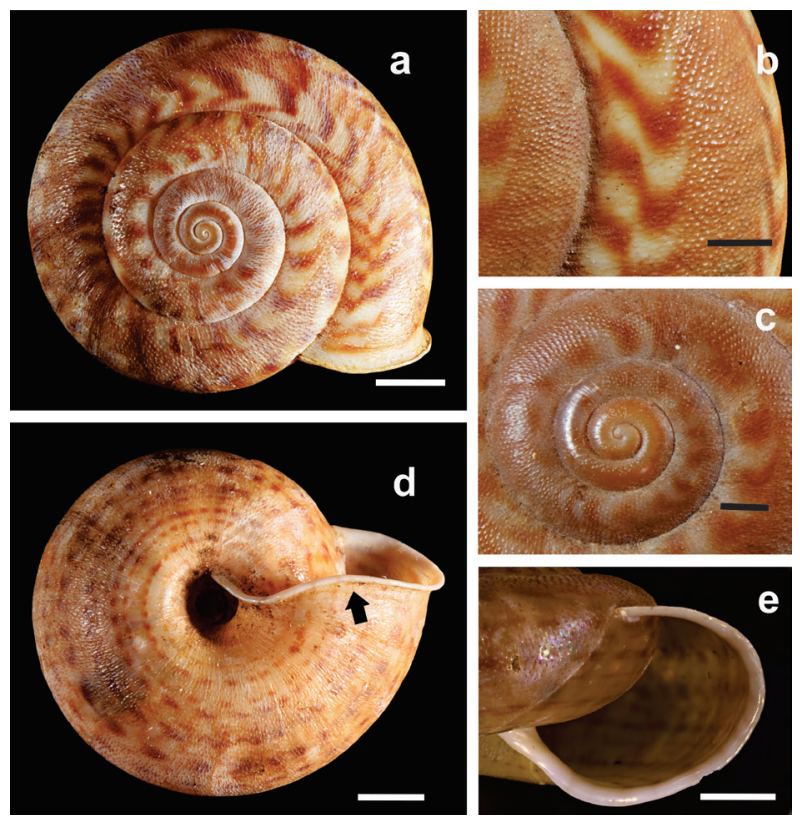

Figure 3 - a, shell morphology of Solaropsis brasiliana. Shell dorsal view (Scale bar $=5 \mathrm{~mm}$ ); $\mathbf{b}$, detail of the body whorl surface sculpture, arrow point to the double band (Scale bar $=2 \mathrm{~mm}$ ); $\mathbf{c}$, detail of the smooth protoconch and upper whorls $($ Scale bar $=2 \mathrm{~mm})$; $\mathbf{d}$, shell ventral view $($ Scale bar $=5 \mathrm{~mm})$; e, shape of the aperture (Scale bar $=5 \mathrm{~mm}$ ).

giving the impression of W-shaped spots (Figure 3b). Ventral shell side with interrupted spiral lines with different thickness (Figure 3d). Suture well impressed. Aperture oblique, with delicate, expanded peristome. Basal lip of aperture with slightly undulating peristome (Figure 3e). Open, narrow, retrospective umbilicus, a little covered 
by peristomal columellar fold. Around umbilicus, interrupted lines closer to each other than in the rest of the ventral shell surface (Figure 3d).

PALLIAL SYSTEM

Pallial complex composed of a lung, pericardial cavity and kidney (Figure 4a). Lung roof mottled with dark black spots lining pulmonary vessels, proximal portion extending beyond top of kidney, distal portion limiting with mantle collar. Even, dark appearance of pulmonary roof, along its length. Kidney thin and long, extending half of lung roof, running parallel to rectum. Internal sculpture of kidney consisting of parallel thin lamellae, thicker in proximal portion. Pericardium located in upper left side of kidney (Figure 4a). Main pulmonary vein shallowly marked along the pulmonary roof, not divided into main branches at distal portion. Smaller, shallow transverse vessels

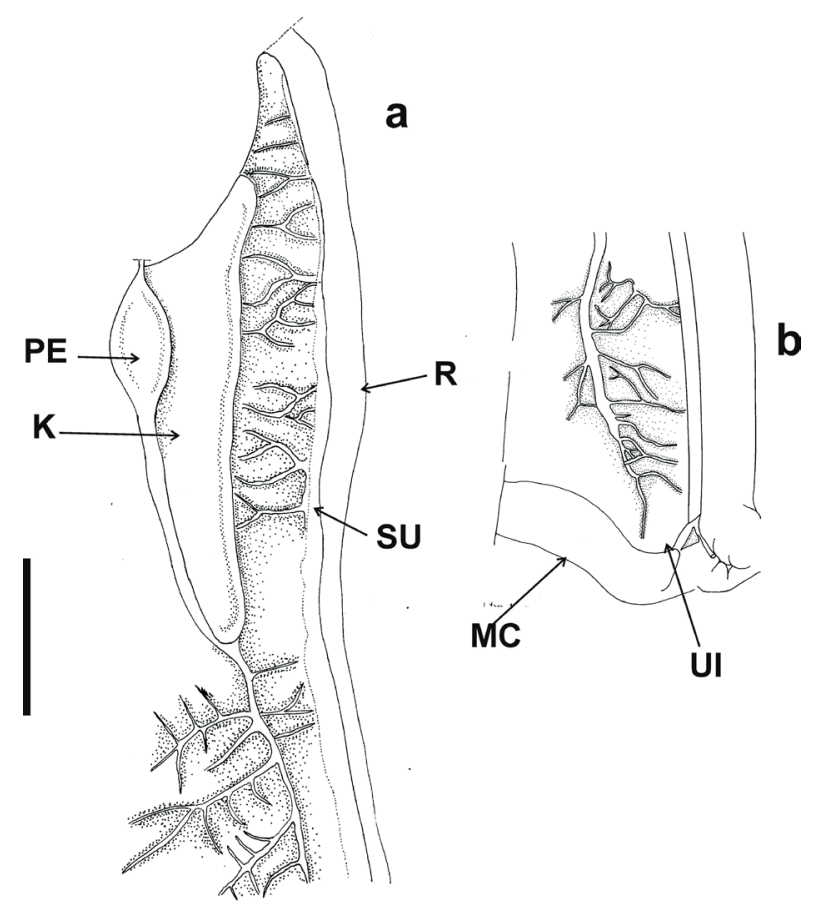

Figure 4 - a, proximal portion of pallial system of Solaropsis brasiliana. Kidney (K); pericardium (PE); rectum (R); secondary ureter $(\mathrm{SU})$. (Scale bar $=5 \mathrm{~mm})$; $\mathbf{b}$, distal portion of pulmonary roof showing union with mantle collar (MC) and ureteric interramus (UI). Scale bar $=5 \mathrm{~mm}$. running between secondary ureter and kidney. Distal portion of pulmonary roof also traverse by several minor vessels. Lung floor or diaphragm thin and translucent. Secondary ureter open along all its length, from top of the lung roof to mantle collar, running parallel to rectum. Ureteric interramus triangular, deeply excavated (Figure 4b).

\section{REPRODUCTIVE SYSTEM}

Ovotestis forming a single, compact mass. Acini rounded, homogeneously yellowish. Hermaphroditic duct markedly convoluted at middle portion, where the vesicula seminalis is located. Hermaphroditic duct running parallel to the columellar muscle and inserting into basal portion of albumen gland. Elongated albumen gland, with a more slender distal portion. Fertilization pouch-spermathecal complex (FPSC) embedded into distal zone of albumen gland, internal, not evident from outside. Albumen gland gradually transforming into spermoviduct with similar thickness, distal limit not clearly demarcated (Figure 5a). Spermoviduct longitudinally divided into a prostate and a glandular female portion along its length. Female portion longitudinally pleated. Bursa copulatrix duct inserts at point of union between distal spermoviduct and free oviduct. Diverticulum of bursa copulatrix thicker than the duct, same length (Figure 5a). Vagina shorter than free oviduct. Prostate portion of spermoviduct continued with vas deferent running towards penioviducal angle, where is attached by numerous, thin muscular filaments, then turning parallel to penis. Vas deferens inserts into proximal portion of epiphallus. Flagellum thick and long (Figure 5b). Epiphallus thicker, even in diameter, transforming into penis with no external limit. Epiphallus straight, 1/3 of penis length. Inner epiphallus wall with longitudinal strength thick pilasters separated by wide spaces (Figure 5b). Penis retractor muscle short and thick, forked. One shorter branch of 

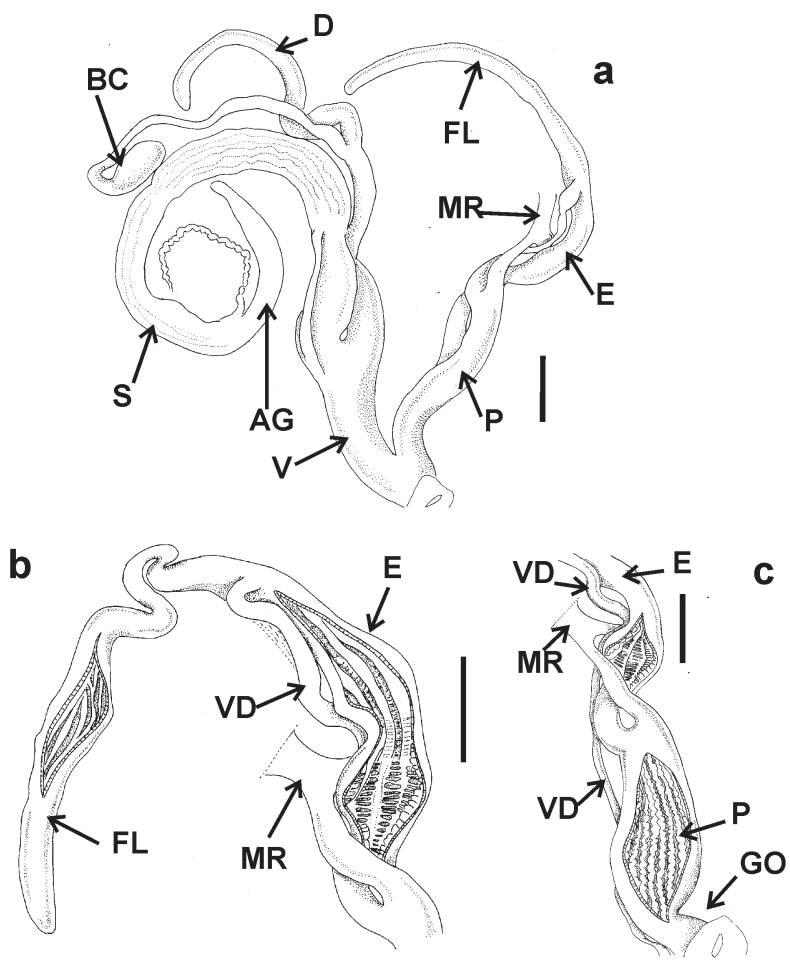

Figure 5 - a-c: a, general view of de reproductive system of Solaropsis brasiliana. Albumen gland (AG); bursa copulatrix (BC); diverticulum (D); epiphallus (E); flagellum (FL); penis retractor muscle (MR); penis $(\mathrm{P})$; spermoviduct $(\mathrm{S})$; vagina (V); b, inner sculpture of proximal epiphallus and flagellum. Epiphallus (E); flagellum (FL); penis retractor muscle (MR); vas deferens (VD); c, inner sculpture of distal epiphallus and penis. Epiphallus (E); genital orifice (GO); penis retractor muscle (MR); penis $(\mathrm{P})$; vas deferens $(\mathrm{VD})$. Scale bar $=5 \mathrm{~mm}$.

penial muscle retractor inserting on proximal penis close to the limit to epiphallus. The other branch, longer, inserting into penis medial portion (Figure $5 \mathrm{~b}, \mathrm{c})$. Vas deferens passing through penial retractor muscle division. Inner sculpture of distal penis wall formed by undulating longitudinal pilasters parallel to each other (Figure $5 \mathrm{c}$ ). Inner proximal portion of penis wall with a different sculpture, consisting on zig-zag longitudinal pilasters. Penial verge absent. Atrium short.

\section{DIGESTIVE SYSTEM}

Radular morphology: Rectangular. Central tooth monocuspid with sharp serrated edges (Figure 6a).
Lateral teeth monocuspid, same length than central tooth (Figure 6b, c). Marginal teeth bicuspids, with a sharply pointed triangular mesocones, basal ectocones sawed, endocones absent (Figure 6d). Jaw arcuate, thin, formed by several short plaques separated by shallow spaces between each other.

Buccal mass muscular, ovoid close to spheroidal. Salivary grands fused over proximal portion of esophageal crop. Oesophagus cylindrical with internal, longitudinal ridges spaced from each other. Oesophagus continuous with a crop wider in diameter with transparent, thin wall. Oesophagial crop separated from a stomach by a short, thinner duct. Intestine lying along columellar side of digestive gland. System ending with a rectum that runs parallel to secondary ureter along the pulmonary roof. Rectum ends in mantle collar.

\section{GEOGRAPHIC RANGE AND HABITAT}

S. brasiliana is recorded in Brazil, in the States of Rio de Janeiro, Espírito Santo, Bahia and Minas Gerais (Figure 1). Additional collections records of few dry shells deposited in Museums exist, mentioning its presence in Ecuador and Peru. Some of these materials were examined, and the
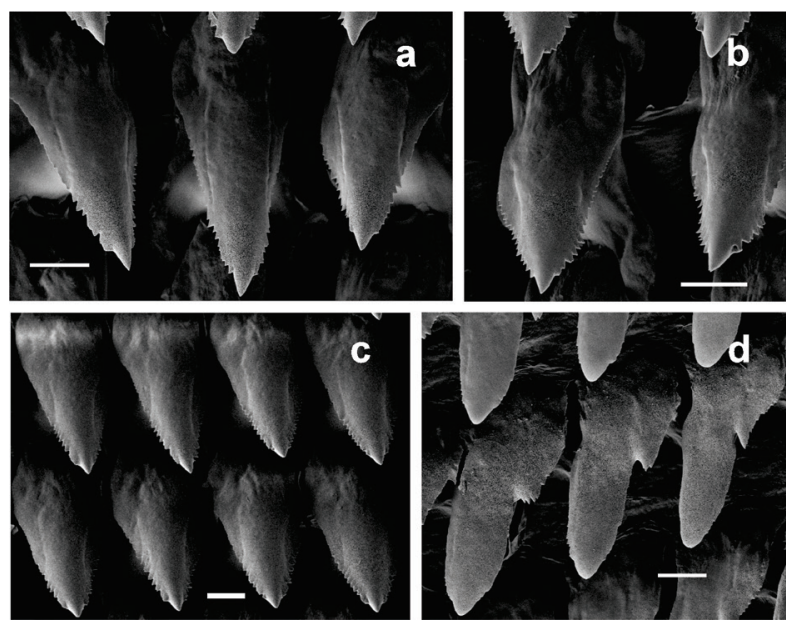

Figure 6 - a, radula of Solaropsis brasiliana, central tooth and first lateral teeth, note the edges serrated. $\mathbf{b}$, forth lateral teeth to the right side of central tooth. $\mathbf{c}$, lateral teeth to the left side of central tooth. d, marginal bicuspid teeth. Scale bar $=10 \mu \mathrm{m}$. 
taxonomic identification is either incorrect or dubious, because is based on single dry shells. Here, we state that $S$. brasiliana is truly restricted to the Atlantic Forest ecoregion classified as the Paraná biogeographical Dominion (Morrone 2014). It is not a frequent or abundant species, being difficult to find alive specimens. Live snails inhabit among leaf litter and below tree trunks laid on the floor were found in rainforest areas in the Tijuca area in Rio de Janeiro. In Ilha Grande specimens were found more frequently between 200 to $500 \mathrm{~m}$ asl, corresponding to the most preserved areas with higher humidity, canopy closure and litter depth associated to lesser luminosity and temperature (Nunes and Santos 2012).

\section{CLADISTIC ANALYSIS}

The cladistic analysis performed, using discrete and continuous characters under implied weighting, resulted in a single tree of maximum fit (43.2327) (Figure 7). The three genera included as part of the ingroup (Labyrinthus, Isomeria and Solaropsis) resulted into monophyletic units, with clade support measures higher for Labyrinthus and Solaropsis (values $>70$ symmetric resampling and $83 \%$ for Solaropsis, and $80 \%$ for Labyrinthus with jackknife method). In the phylogenetic hypothesis obtained, Isomeria is sister group of Labyrinthus, and this clade (node 32) is sister group of Solaropsis. The monophyly of Solaropsis (node 42) is supported by continuous character 3 and discrete characters 23[1] lung roof extending beyond top of kidney, 28[1] flagellum short and thick, 40[0] internal sculpture of vagina consisting in long straight folds and 45[0] jaw ribbed.

The relationships of the species of Solaropsis, included in this study, are completely solved. Solaropsis brasiliana is sister group of Solaropsis gibboni (node 43), supporting this relationship the synapomorphies 32[0] absence of penis sheath, 36 [1] thick penial retractor muscle and 37[1] forked penis retractor muscle. Apomorphies of $S$. brasiliana are characters 34[2] inner wall of penis with several, longitudinal pilasters and 42[1] bursa

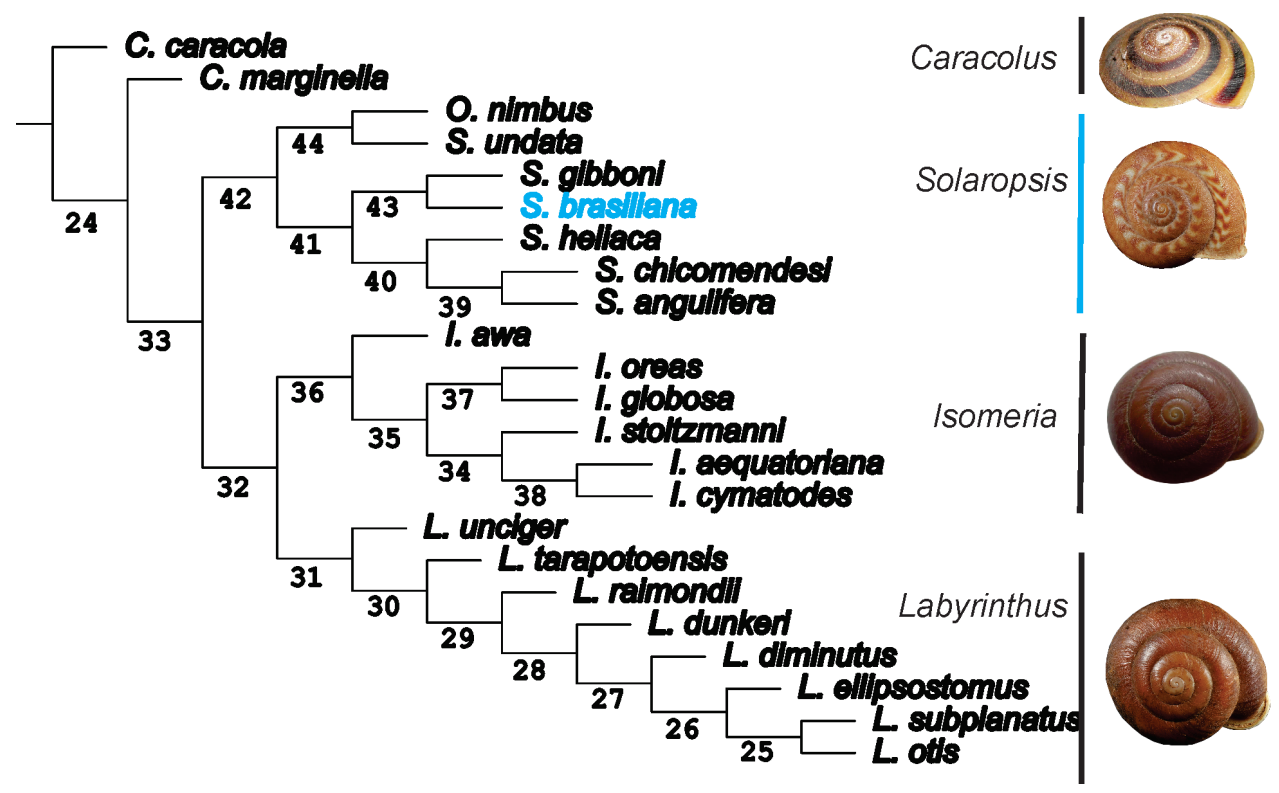

Figure 7 - Single tree obtained in the phylogenetic analysis of the South American Pleurodontidae (Solaropsis, Isomeria and Labyrinthus), including species with known anatomy. Tree is rooted in the genus Caracolus, sister group of the remaining species according to Cuezzo (2003). Numbers below branches indicate the nodes of the clades. 
copulatrix sac reflexed over proximal portion of duct.

Solaropsis undata, the type species of the genus, is sister group of $O$. nimbus (node 44).

Isomeria (node 36) is a monophyletic genus that show low clade support with symmetric resampling and jackknife measures (42\%). In the present hypothesis, the monophyly of Isomeria is supported by the continuous characters 2,5 and the discrete characters 17[2] umbilicus partly overlapped, 20[4] general shape of aperture quadrangular, 30[1] epiphallus partially enclosed into penis sheath, and 31[1] epiphallus proximal portion reflexed over distal part.

Labyrinthus (node 31) is monophyletic and supported by characters 2, 5 and discrete characters $6[2]$ aperture heavily obstructed by teeth and lamellae, 8[1] presence of basal lip teeth and 20[1] aperture ogive-shaped. This genus is formed by two main clades, one composed by Labyrinthus unciger (Petit 1838), supported by continuous character 5 and discrete characters 9[0] basal side of aperture with conical peristomal teeth, 39[1] penis reflexed over epiphallus.

The other clade (node 30) is composed by the resting species of Labyrinthus considered in the analysis. It is supported by characters 12[1] presence of lamella in the inner palatal wall, 13[2] Y-shaped palatal lamella and 26[0] ovotestis digitiform alveoli.

\section{DISCUSSION}

The study of the genus Solaropsis has always been difficult because, while shells have always captured the attention of collectors, specimens are not frequently found alive in humid forest areas or are found in low abundance. Consequently, shells of different species were preserved, and are available in malacology collections at different institutions. On the other hand, soft parts were seldom preserved, then, anatomy and molecular studies on this genus are scarce.

The distribution of Solaropsis in South America is closely linked to humid forest areas. Most of their studied species are distributed, considering only South America, in two areas, north-western South America and Amazonian forest, and a south-eastern part with Paraná and Atlantic forest. Very few species records are located in the Dry diagonal of South America (Dry Chaco, Cerrado and Caatinga ecoregions). This kind of distribution is mostly coincident with that of some group of insects (Morrone and Coscaron 1996). Amazonia is a composite area (Amorim 2001), and according to Nihei and Carvalho (2007) north-western Amazonia is closely related to the Caribbean subregion, whereas south-eastern Amazonia is related to the Chacoan and Paraná subregions. Although this pattern seems to be related to Solaropsis species, more information on the distribution of most of its species is needed before arriving at any biogeographical conclusion.

Solaropsis brasiliana is an emblematic species from eastern Brazil. Pilsbry (1889) classified the known species of Solaropsis based on shell size, periphery and thickness, into two main groups. Solaropsis brasiliana belonged to the group of larger shells, where the possession of shell granules and their location on the shell surface were diagnostic characters. Pilsbry (1889) related S. brasiliana to $S$. heliaca because both have granules distributed in more or less distinct oblique rows. However, in the present phylogenetic hypothesis, shell granules over the body whorl surface are common to all species with the exception of Solaropsis gibboni. Other species of the genus such as $S$. feisthamelli, also lack shell granules, but it was not included in the cladistic analysis. Pilsbry (1889) also stated, when describing Solaropsis brasiliana in his Manual of Conchology, that he had never saw a specimen with hirsute cuticle. Probably, he could have seen eroded specimens, or old shells that 
have lost their periostracal hairs. We have found live specimens with short, dense hairs all over their shell surface and others, less hirsute. Short hairs have also been described in some other species of Solaropsis, such as in S. chicomendesi Cuezzo and Fernandez 2001, S. angulifera Hass 1955, S. marmatensis (Pfeiffer 1854), where hairs are also short but sparsely distributed on dorsal surface (Cuezzo and Fernandez 2001, Cuezzo 2002, 2003). Coloration is also variable in S. brasiliana, shells in general are chestnut dark, but some are lighter. Shell size and the degree of overlap of the peristome over the umbilicus are, on the other hand, less variable characters when comparing several shells of this species.

Pallial system in S. brasiliana is distinctive in that its lung roof is darkly pigmented. The kidney, usually longer in other species of Solaropsis, and in some Labyrinthus, is here only half of the pulmonary roof length. The secondary ureter in $S$. brasiliana is completely open along all its length. Among other species of the genus, only S. gibboni (Pfeiffer 1846) and S. undata (Lightfoot 1786) are known to have an open ureter. Diagnostic characters from the reproductive system of $S$. brasiliana are its flagellum, which is thick and longer than any other currently known species of the genus, epiphallus straight, the penial retractor muscle forked, and the vas deferens running through the space between the branches.

Solaropsis brasiliana has often been confused with Solaropsis pilsbryi Ihering 1900, and their distributional ranges were mixed as product of this confusion. S. pilsbryi is distributed further north than $S$. brasiliana, inhabiting mainly in Bahia State. S. brasiliana seems to be more common in Rio de Janeiro State although there are also some localities of occurrences in Bahia, Espírito Santo and Minas Gerais. It can be differentiated from S. pilsbryi by its wider aperture shell diameter; its umbilicus not completely overlapped by the apertural lip and smaller shell dimensions. The anatomy of
Solaropsis pilsbryi is unknown, for only dry shells are available.

The phylogenetic hypothesis of relationships obtained in the present study shows high support for the monophyly of the genus and resolved relationships within the clade. Previous existing hypothesis (Cuezzo 2003) could not resolve the relationships between Solaropsis brasiliana and the other species studied. Here, we provided more accurate anatomical information for Solaropsis brasiliana, also introducing continuous characters that improved and clarified its relationships with the remaining species.

The genus Olympus Simone 2010 resulted as sister group of $S$. undata, the type species of Solaropsis, consequently indicating that Olympus is a Solaropsis. Both genera share the tiny shell granules on the surface, similar spotty patterns on the shell and absence of teeth in the aperture. They differed in that Olympus spire is higher than in most of Solaropsis species, and also it's shell is smaller than most described Solaropsis. Anatomically, one of the outstanding characters that distinguish Olympus from most Solaropsis species is the lack of a diverticulum in the bursa copulatrix (Simone 2010). However, S. undata does not present a truly diverticulum of the bursa copulatrix, as it is present in the remaining species of the genus, but only a basal thickening in some specimens (Tillier 1980). The shape and length of the kidney in both genera is similar, the lack of external differentiation between epiphallus and penis is also a common character in most helicoidean groups. However, as only a minor proportion of Solaropsis species is anatomically studied, the results of the phylogenetic analysis concerning the validity of Olympus as a separate genus from Solaropsis, should be carefully considered until more information is available.

Solaropsis is a typical forest group, basal to the South American Pleurodontidae (Cuezzo 2003), that is clearly threatened because of the accelerated area destruction. For this reason, it is necessary to 
increase taxonomic studies on this rare group of land snails.

\section{ACKNOWLEDGMENTS}

We would like to thanks the curators of the following Institutions for allowing working at their malacology collections or for providing material and photographs A. Pimenta, N. Campos Salgado (MNRJ, Brazil), P. Bouchet, V. Heros (MNHN, France), R. Bieler (FMNH, USA) and A. Barragan (QCAZ, Ecuador). To Prof. Dr. Antonio Carlos de Freitas (IBRAG-UERJ) who kindly provide us with a photograph of a live Solaropsis brasiliana. MGC would like to thank Universidade do Estado do Rio de Janeiro (UERJ, Brazil) for financial support while working in Brazil. MGC is a researcher of the Argentine National Council of Scientific Research (CONICET). SBS thanks Fundação Carlos Chagas Filho de Amparo à Pesquisa do Estado do Rio de Janeiro (FAPERJ) for financial support APQ1 E-26/110.402/2010, E-26/110.362/2012 and E-26/111.573/2013, IBAMA for Sisbio license 10812-1; INEA for license 18/2007; CEADS/UERJ for field research facilities. APL thanks PIBIC/ UERJ, Conselho Nacional de Desenvolvimento Científico e Tecnológico (CNPq) for the Scientific Initiation scholarship (2014-2015).

\section{REFERENCES}

ALBERS JC. 1850. Die Heliceen, nach natürlicher Verwandtschaft systematisch Geordnet Erste Ausgabe, Verlag. Berlín: Von Th. Chr. Fr. Enslin, 223 p.

ALBERS JC. 1860. Die Heliceen Nach Natürlicher Verwandtschaft Systematisch Geordnet. I-XVIII, Leipzig, $359 \mathrm{p}$.

AMORIM DS. 2001. Dos Amazonias. In: Llorente J and Morrone JJ (Eds), Introducción a la biogeografía en Latinoamérica: conceptos, teorías, métodos y aplicaciones, México, D.F.: Las Prensas de Ciencias, UNAM, p. 245255.

BECK H. 1837. Index Moluscorum praesentis aevi Musei Principis Augustissimi Christiani Frederici. Stanford Library, Hafniae, 100 p.

CAMPOS SALGADO N AND DOS SANTOS COELHO AC. 2003. Moluscos terrestres do Brasil (Gastropodes operculados ou não, exclusive Veronicellidae, Milacidae e Limacidae). Rev Biol Trop 51: 149-189.

CUEZZO MG. 2002. On Solaropsis Beck: new anatomical data and its systematic position within Helicoidea. Pap Avul Zool 42: 31-46.

CUEZZO MG. 2003. Phylogenetic analysis of the Camaenidae (Mollusca: Stylommatophora) with especial emphasis on the American taxa. Zool J Linn Soc 138: 449-476.

CUEZZO MG. 2006. On a new species of Isomeria Beck and redescription of species of Labyrinthus Beck from South America (Gastropoda: Stylommatophora: Camaenidae) Zootaxa 1221: 1-23.

CUEZZO MG AND FERNANDEZ I. 2001. A new species of the land gastropod genus Solaropsis Beck, 1837 from Bolivia. Veliger 44: 315-324.

DESHAYES GP. 1832. Encyclopédie méthodique: Histoire naturelle des vers. Panckoucke, Paris, Agasse, 2, p. 2145 2594.

FERÚSSAC AÉJPF D`A DE AND DESHAYES GP. 1851. Histoire naturelle générale et particulière des mollusques terrestres et fluviatiles, 2. Paris: Baillière, $260 \mathrm{p}$.

FRÝDA J, HAUSDORF B, PONDER WF, VALDÉS Á AND WARÉN A. 2005. In: Bouchet P and Rocroi JP (Eds), Classification and Nomenclator of Gastropod Families, Germany: Malacologia 47(1-2), ConchBooks: Hackenheim, 397 p.

GOLOBOFF P, FARRIS J AND NIXON K. 2003. T.N.T. Tree Analysis Using New Technology. Program and documentation. Available at: http://www.zmuc.dk/public/ phylogeny/tnt.

GOLOBOFF P, FARRIS J AND NIXON K. 2008. TNT, a free program for phylogenetic analysis. Cladistics 24: 774-786.

HAAS F. 1953. Mollusks from Ilha Grande, Rio de Janeiro, Brazil. Fieldiana Zool 34: 203-209.

HIDALGO JG. 1869. Moluscos del viaje al pacifico. Primera Parte, Univalvos terrestres. Madrid: M. Ginesta, 144 p.

HUPÉ H. 1853. Observations sur l'Helix pellis-serpentis Chemn, description d'espèces nouvelles du genre Hèlice. Révue et Magazin de Zoologic 5(2): 296-303.

KOBELT W. 1879. Illustrirtes Conchylienbuch. Nürnberg: von Bauer and Raspe, $264 \mathrm{p}$.

LOWËNBERG-NETO P. 2014. Neotropical region: a shapefile of Morrone's (2014) biogeographical regionalisation. Zootaxa 3802(2): 300.

MIRANDE M, JEREP FC AND VANEGAS-RÍOS JA. 2013. Phylogenetic relationships of the enigmatic Carlastyanax aurocaudatus (Eigenmann) with remarks on the phylogeny of the Stevardiinae (Teleostei: Characidae). Neotrop Ichthyol 11: 747-766.

MORRETES FL. 1949. Ensaio de Catálogo dos Moluscos do Brasil. Archiv Mus Paranaense 7: 5-216.

MORRONE JJ. 2014. Cladistic biogeography of the Neotropical region: identifying the main events in the 
diversification of the terrestrial biota. Cladistics 30: 202214.

MORRONE JJ AND COSCARON MC. 1996. Distributional patterns of the American Peiratinae (Heteroptera: Reduviidae). Zool Medel Leiden 70: 1-15.

NIHEI SS AND CARVALHO CJB. 2007. Systematics and biogeography of Polietina Schnabl and Dziedzicki (Diptera, Muscidae): Neotropical area relationships and Amazonia as a composite area. Syst Entomol 32: 477-501.

NIXON K. 2002. WINCLADA v.1.00.08. Character analysis program. Published by the author.

NORDSIECK H. 1986. The system of the Stylommatophora (Gastropoda), with special regard to the systematic position of the Clausiliidae. Arch Moll 117: 93-116.

NUNES GKM AND SANTOS SB. 2012. Environmental factors affecting the distribution of land snails in the Atlantic Rain Forest of Ilha Grande, Angra dos Reis, RJ, Brazil. Braz J Biol 72: 79-86.

PFEIFFER L. 1848. Monographia heliceorum viventium. Sistens descriptiones systematicas et criticas omnium huius familiae generum et specierum hodie cognitarum. 2 . Lipsiae: F.A. Brockhaus, 594 p.

PFEIFFER L. 1868. Monographiae heliceorum viventium. Sistens descriptiones systematicas et criticas omnium huius familiae generum et specierum hodie cognitarum. 5 . Lipsiae: FA Brockhaus, 565 p.

PILSBRY H. 1889. Manual of Conchology; structural and systematic. Acad Nat Sci, Conchological Section, V: Helicidae. Philadelphia, 226 p.

REEVE LA. 1851. Monograph of the genus Helix. Conchologica Iconica: illustrations of the shells of the molluscous animals, VII. London: 210 pls.

RICHARDSON L. 1985. Camaenidae: Catalogue of species. Tryonia 12: 1-479.

SANTOS SB, RODRIGUES CL, NUNES GKM, BARBOSA AM, LACERDA LEM, MIYAHIRA IC, VIANA TA, OLIVEIRA JL, FONSECA FC AND SILVA PSC. 2010. Estado do conhecimento da fauna de invertebrados nãomarinhos da Ilha Grande (Angra dos Reis, RJ). Oecologia Australis 14: 504-549.

SERENO P. 2007. Logical basis for morphological characters in phylogenetics. Cladistics 23: 565-587.

SIMONE LR. 2006. Land and freshwater Molluscs of Brazil. São Paulo: EGB, Fapesp, 390 p.
SIMONE LR. 2010. A new genus and species of camaenid from the Amazon Rainforest, Brazil (Pulmonata, Helicoidea). J Conchol 40: 149-161.

SOLEM A. 1966. The Neotropical land snail genera Labyrinthus and Isomeria (Pulmonata: Camaenidae). Fieldiana, Zoology 50: 1-217.

TILLER S. 1989. Comparative morphology, phylogeny and classification of land snails and slugs (Gastropoda: Pulmonata: Stylommatophora). Malacologia 30: 1-303.

TILLIER S. 1980. Gasteropodes terrestres et fluviátiles de Guyane Française. Mem Mus Nat d'Histoire Nat, Serie A (Zoologie) 118: 3-188.

TOMPAAS. 1984. Land Snails (Stylommatophora). In: Tompa AS, Verdonk NH and Van Der Biggelaar JA (Eds), The Mollusca, 7. London: Academic Press, p. 47-140.

VON IHERING H. 1900. Os caracoes do genero Solaropsis. Rev Mus Paulista 4: 539-549.

VON IHERING H. 1912. Analyse der Sud-Amerikanischen Heliceen. Acad Nat Sci Philadelphia 15(II) : 475-500.

WADE CM, HUDELOT C, DAVISON A, NAGGS F AND MORDAN P. 2007. Molecular phylogeny of the helicoid land snails (Pulmonata: Stylommatophora: Helicoidea), with special emphasis on the Camaenidae. J Moll Stud 73: 411-415.

WADE CM, MORDAN PB AND NAGGS F. 2006. Evolutionary relationships among the Pulmonate land snails and slugs (Pulmonata, Stylommatophora). Biol J Linn Soc 87: 593-610.

WURTZ CB. 1955. The American Camaenidae. Proc Acad Nat Sci Philadelphia 57: 99-143.

ZILCH A. 1959-1960. Gastropoda: Euthyneura. In: Borntraeger G (Ed), Handbuch der Paläozoologie, Berlin, p. 1-834.

\section{SUPPLEMENTARY MATERIAL}

Table SI - List of characters and state characters used in the matrix for cladistic analysis. 0-5 are continuous characters, 6-45 are discrete characters.

Table SII - Data matrix for the (1-5) continuous characters, based on shell measurements, (6-46) discrete characters, based on anatomy and 23 taxa, built with WINCLADA and analyzed with TNT in this study. Missing characters are indicated by "??". 